Supplement of Atmos. Chem. Phys., 17, 1805-1828, 2017

http://www.atmos-chem-phys.net/17/1805/2017/

doi:10.5194/acp-17-1805-2017-supplement

(C) Author(s) 2017. CC Attribution 3.0 License.

(c) (i)

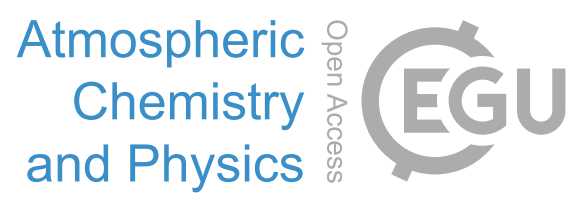

Supplement of

\title{
Differences in BVOC oxidation and SOA formation above and below the forest canopy
}

Benjamin C. Schulze et al.

Correspondence to: Robert J. Griffin (rob.griffin@ rice.edu)

The copyright of individual parts of the supplement might differ from the CC-BY 3.0 licence. 
Table S1. Description of values used in calculation of deposition velocities of particles and gases ${ }^{1}$. H indicates Henry's Law Coefficient, $\mathrm{f}_{\mathrm{o}}$ is the reactivity factor, and MCM species indicates to which compounds (or classes of compounds) the parameters were applied.

\begin{tabular}{|c|c|c|c|c|}
\hline Name & $\begin{array}{l}\text { Diffusivity } \\
\qquad\left(\mathrm{m}^{2} \mathrm{~s}^{-1}\right)\end{array}$ & $\begin{array}{c}\mathbf{H} \\
\left(\mathbf{M} \mathbf{a t m}^{-1}\right)\end{array}$ & $f_{o}$ & MCM Species \\
\hline $\mathrm{H} 2 \mathrm{O} 2$ & $1.75 \times 10^{-5}$ & $1.1 \times 10^{5}$ & 1 & Hydrogen Peroxide \\
\hline Formic & $1.34 \times 10^{-5}$ & $5.6 \times 10^{3}$ & 0 & Formic Acid \\
\hline HNO3 & $1.15 \times 10^{-5}$ & $3.2 \times 10^{5}$ & 1 & Nitric Acid \\
\hline HMHP & $1.14 \times 10^{-5}$ & $1.3 \times 10^{6}$ & 0.1 & Hydroxymethylhydroperoxide \\
\hline $\mathrm{HAC}$ & $1.06 \times 10^{-5}$ & $2.0 \times 10^{3}$ & 0 & Hydroxyacetone \\
\hline PAA & $1.04 \times 10^{-5}$ & $5.2 \times 10^{2}$ & 0.1 & Peroxyacetic acid \\
\hline HDC4 & $9.01 \times 10^{-6}$ & $2.0 \times 10^{3}$ & 0 & $\mathrm{C}_{4}$ Hydroxy dicarbonyls \\
\hline DHC4 & $8.92 \times 10^{-6}$ & $2.0 \times 10^{3}$ & 0 & C4 Dihydroxy carbonyls \\
\hline HPALD & $8.45 \times 10^{-6}$ & $4.0 \times 10^{4}$ & 0 & Isoprene hydroperoxyaldehyde \\
\hline ISOPOOH/IEPOX & $8.37 \times 10^{-6}$ & $4.0 \times 10^{4}$ & 0 & $\begin{array}{l}\text { Isoprene hydroxy- } \\
\text { hydroperoxide and epoxides }\end{array}$ \\
\hline PROPNN & $8.34 \times 10^{-6}$ & $1.0 \times 10^{4}$ & 0 & Propanone nitrate \\
\hline ISOPN & $7.50 \times 10^{-6}$ & $5.0 \times 10^{3}$ & 0 & Isoprene hydroxy nitrates \\
\hline MACN/MVKN & $7.45 \times 10^{-6}$ & $6.0 \times 10^{3}$ & 0 & $\begin{array}{l}\text { Methacrolein and Methyl } \\
\text { vinyl ketone hydroxy nitrates }\end{array}$ \\
\hline INP & $7.12 \times 10^{-6}$ & $5.0 \times 10^{3}$ & 0 & $\begin{array}{l}\text { Isoprene nitrooxy } \\
\text { hydroperoxides }\end{array}$ \\
\hline MTNP & $5.98 \times 10^{-6}$ & $1.0 \times 10^{3}$ & 0 & $\begin{array}{l}\text { Monoterpene nitrooxy } \\
\text { hydroperoxides }\end{array}$ \\
\hline $\mathrm{ANIT}^{2}$ & $5.98 \times 10^{-6}$ & $1.0 \times 10^{3}$ & 0 & Other monoterpene nitrates \\
\hline OTHER $^{2}$ & $5.98 \times 10^{-6}$ & $1.0 \times 10^{3}$ & 0 & Other $\alpha$-pinene products \\
\hline ISOPOOH $2^{3}$ & $8.37 \times 10^{-6}$ & $1.0 \times 10^{4}$ & 0 & Other isoprene hydroperoxides \\
\hline ISOPNIT $^{4}$ & $7.12 \times 10^{-6}$ & $5.0 \times 10^{3}$ & 0 & Other isoprene nitrates \\
\hline ISOPOTHER $^{4}$ & $7.12 \times 10^{-6}$ & $5.0 \times 10^{3}$ & 0 & $\begin{array}{l}\text { Other isoprene oxidation } \\
\text { products }\end{array}$ \\
\hline $\mathrm{RAD}^{5}$ & 0 & 0 & 0 & Alkoxy and peroxy radicals. \\
\hline $\mathrm{MACR}^{6}$ & $5.02 \times 10^{-5}$ & $6.5 \times 10^{0}$ & 1 & Methacrolein \\
\hline $\mathrm{MVK}^{6}$ & $5.02 \times 10^{-5}$ & $4.1 \times 10^{1}$ & 1 & Methyl vinyl ketone \\
\hline $\mathrm{CH} 3 \mathrm{CHO}^{6}$ & $7.12 \times 10^{-6}$ & $1.5 \times 10^{1}$ & 0 & Acetaldehyde \\
\hline GLY & $4.49 \times 10^{-5}$ & $4.1 \times 10^{4}$ & 0 & Glyoxal \\
\hline $\mathrm{PAN}^{6}$ & $7.02 \times 10^{-5}$ & $5.0 \times 10^{0}$ & 0.1 & Peroxyacetylnitrates \\
\hline ACETOL $^{6}$ & $7.12 \times 10^{-6}$ & $2.4 \times 10^{6}$ & 1 & Acetone Alcohol \\
\hline $\mathrm{HCHO}^{6}$ & $3.43 \times 10^{-5}$ & $2.3 \times 10^{4}$ & 1 & Formaldehyde \\
\hline $\mathrm{N} 2 \mathrm{O} 5^{6}$ & $5.81 \times 10^{-5}$ & $1 \times 10^{20}$ & 1 & Dinitrogen Pentoxide \\
\hline
\end{tabular}

${ }^{1}$ Unless otherwise indicated, values obtained from Nguyen et al. (2015).

${ }^{2}$ Values assumed the same as MTNP.

${ }^{3}$ Values assumed the same as ISOPOOH.

${ }^{4}$ Values assumed the same as INP.

${ }^{5}$ Radical species assumed to undergo negligible deposition.

${ }^{6}$ Diffusivity values obtained from Ashworth et al. (2015). Henry's Law coefficients obtained from Sander et al. (1999). Reactivity factor of MACR and MVK adjusted to 1 in accordance with findings of Karl et al. (2010). 

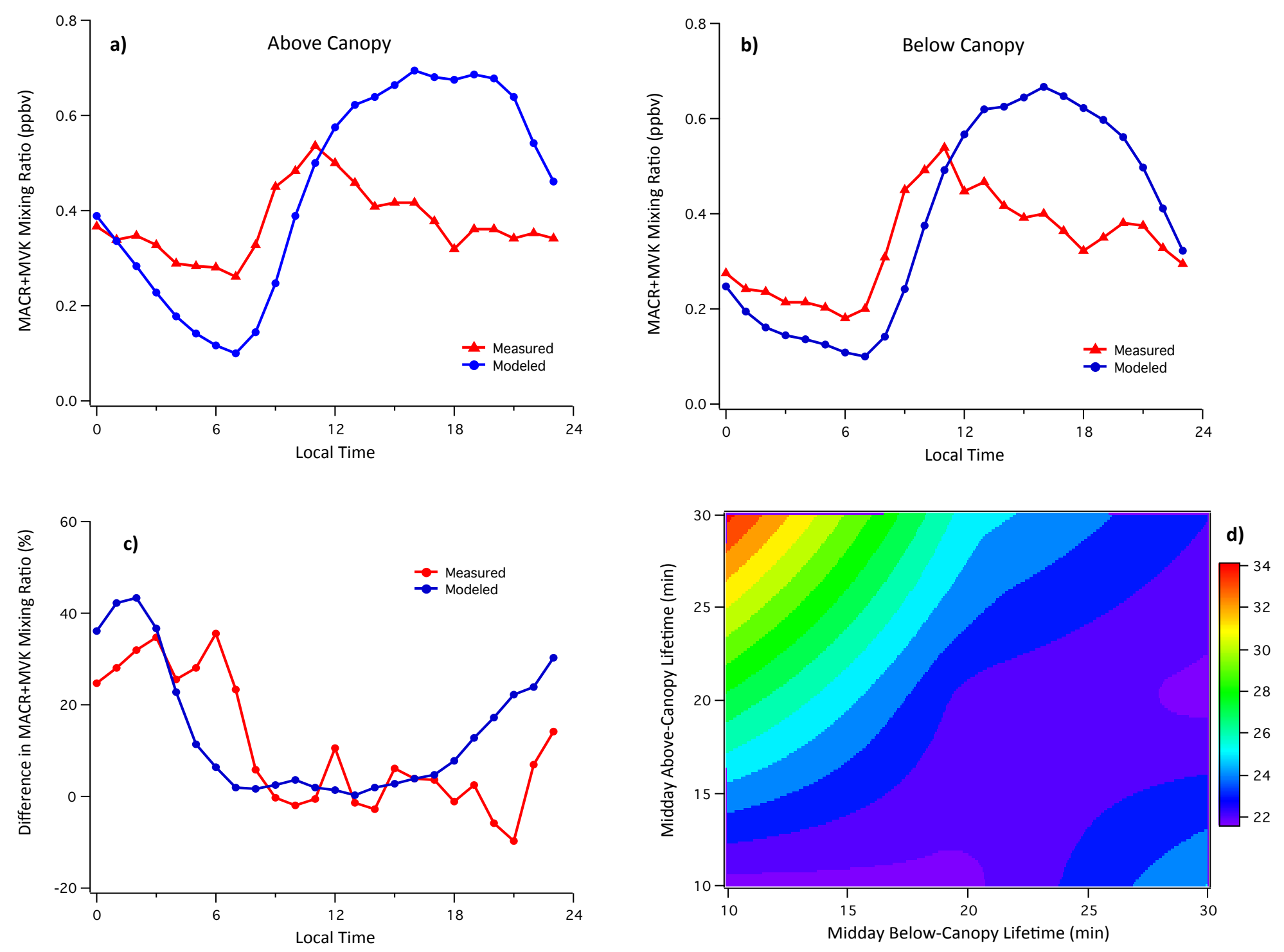

Figure S1. Comparison of above-canopy (a) and below-canopy (b) median MACR+MVK measurements during CABINEX 2009 to 0D model predictions. (c) Comparison of the measured and modeled differences (\%) in MACR+MVK mixing ratios between the above-canopy and below-canopy environments. Positive values indicate higher concentrations above the canopy than below. (d) Cost function output for analysis of different above and below canopy lifetimes with respect to transport. Smaller values indicate better agreement with measured concentrations. 


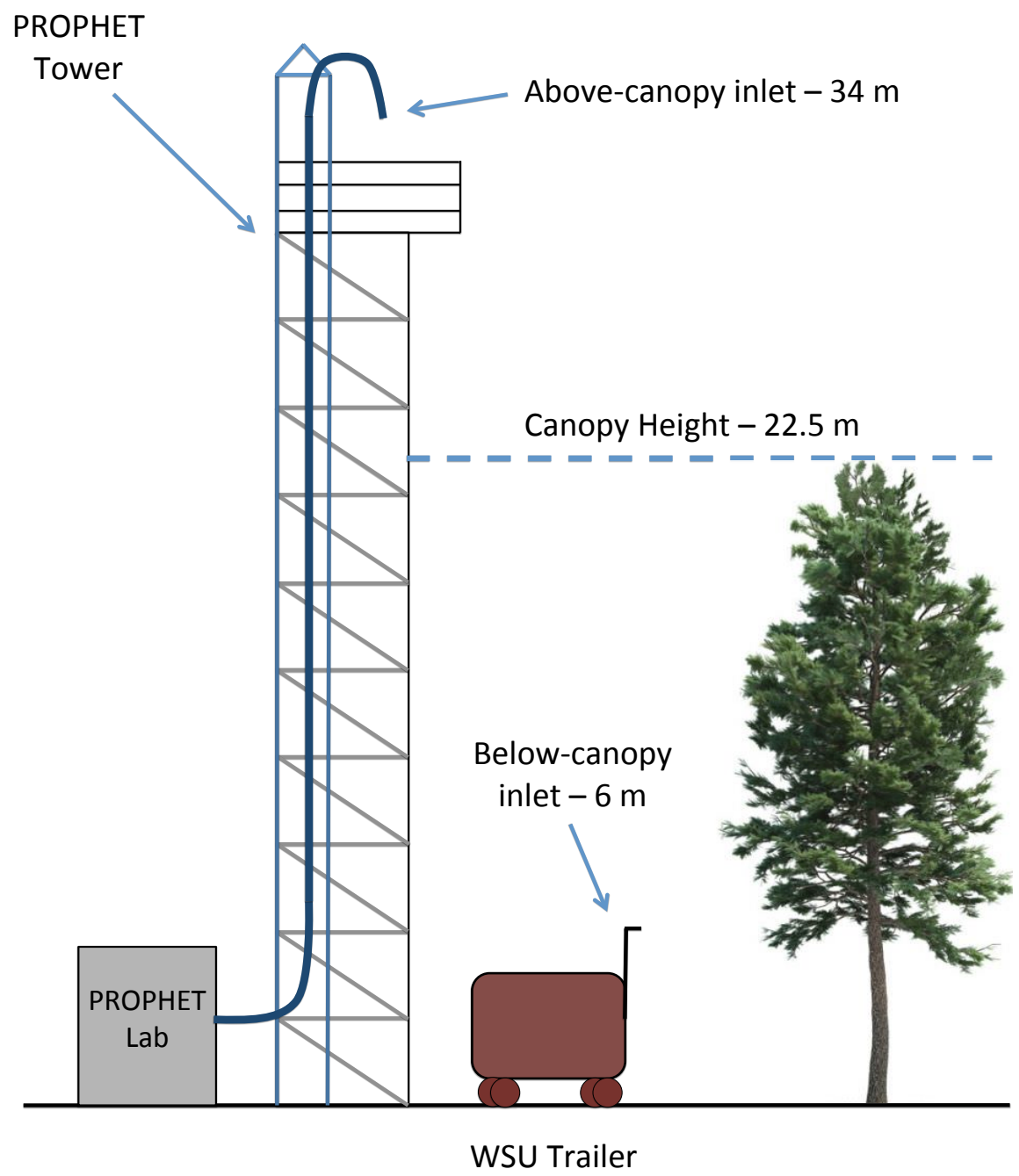

Figure S2. Depiction of the PROPHET tower and inlet locations used during CABINEX 2009. 

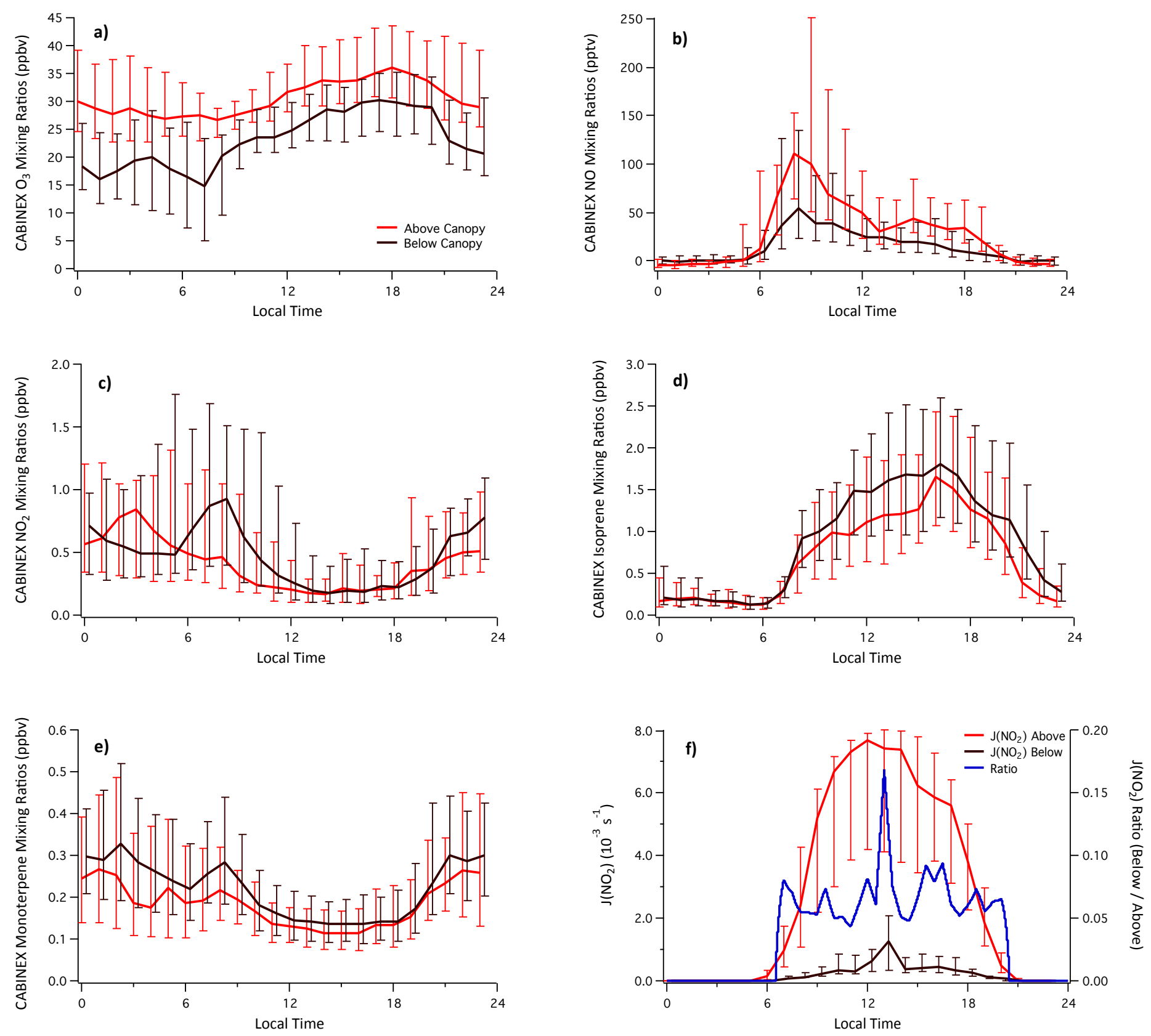

Figure S3. CABINEX 2009 measurements of ambient (a) $\mathrm{O}_{3}$ (ppbv), (b) $\mathrm{NO}$ (pptv), (c) $\mathrm{NO}_{2}$ (ppbv), (d) isoprene (ppbv), (e) monoterpenes (ppbv), and (f) the photolysis rate of $\mathrm{NO}_{2}\left(\mathrm{JNO}_{2}\right)\left(10^{-3} \mathrm{~s}^{-1}\right)$. Lighter (red) colored lines indicate above-canopy measurements; darker-colored (black) lines indicate belowcanopy measurements. Solid lines represent median measured values, while upper and lower bars represent $75^{\text {th }}$ and $25^{\text {th }}$ percentiles respectively. Below-canopy values have been offset by 15 minutes to aid interpretation. 

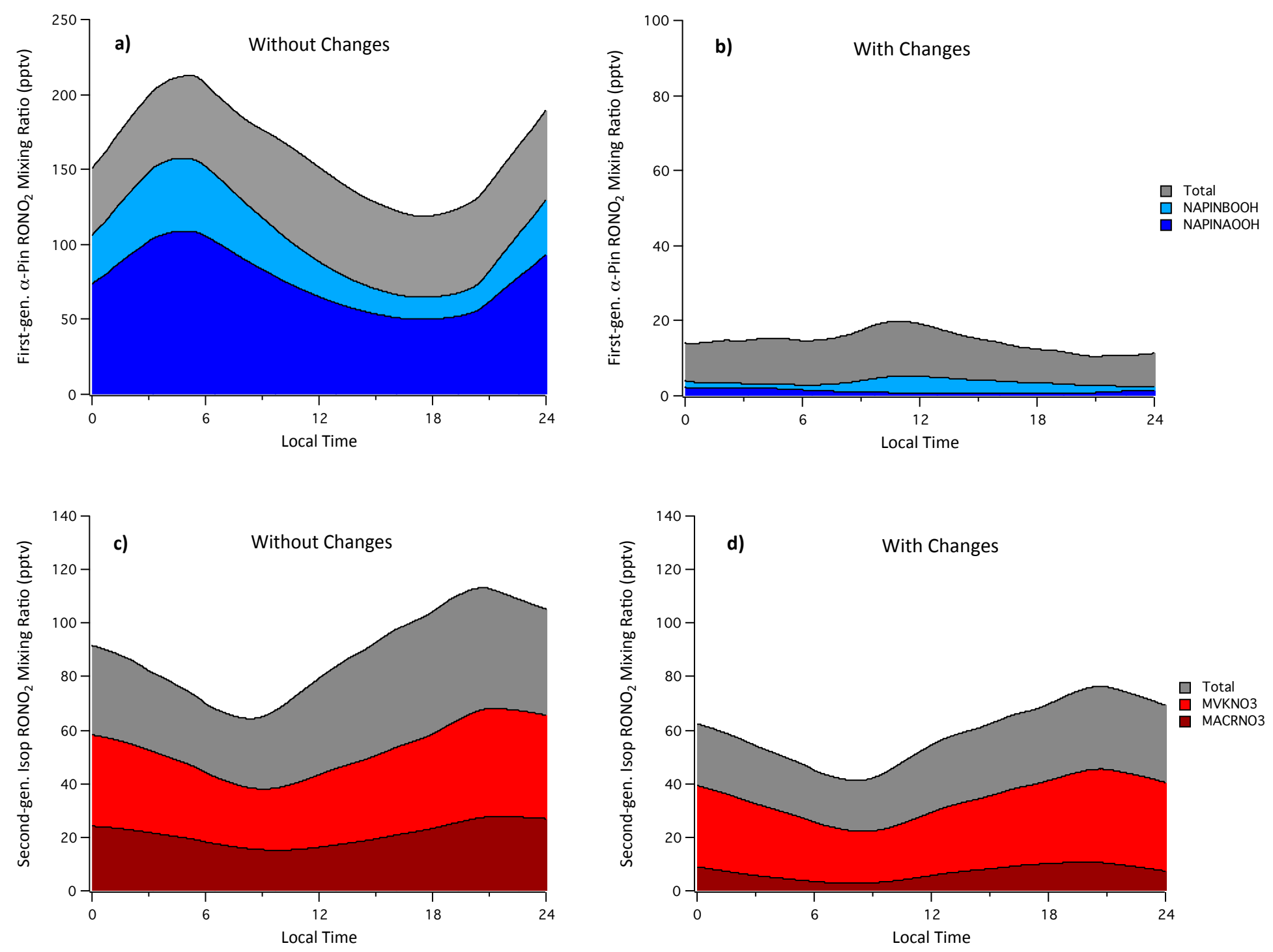

Figure S4. Concentrations of major $\mathrm{RONO}_{2}$ products from $\alpha$-pinene $(\mathbf{a}, \mathbf{b})$ and isoprene (c,d) above the canopy without (left) and with (right) the changes to the chemical mechanism described in Section 2.6. 

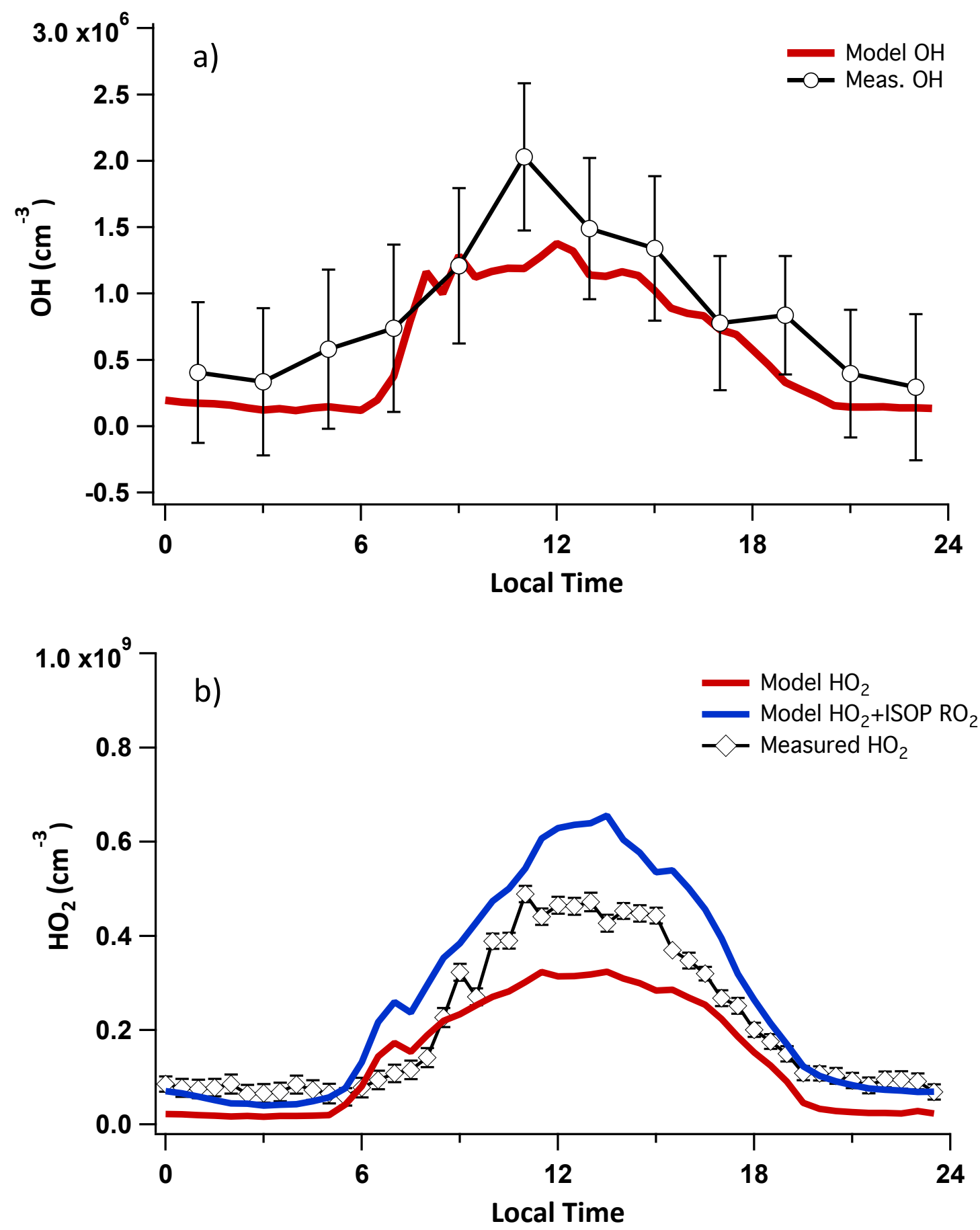

Figure S5. (a) Comparison of above-canopy median $\mathrm{OH}$ measurements during CABINEX 2009 to 0D model predictions for the ambient CABINEX model scenario. (b) Comparison of above-canopy median $\mathrm{HO}_{2}$ measurements during CABINEX 2009 to $0 \mathrm{D}$ model predictions of $\mathrm{HO}_{2}$ and $\mathrm{HO}_{2}+$ isoprene $\mathrm{RO}_{2}$ for the ambient CABINEX model scenario. Error bars indicate median measurement precision. 

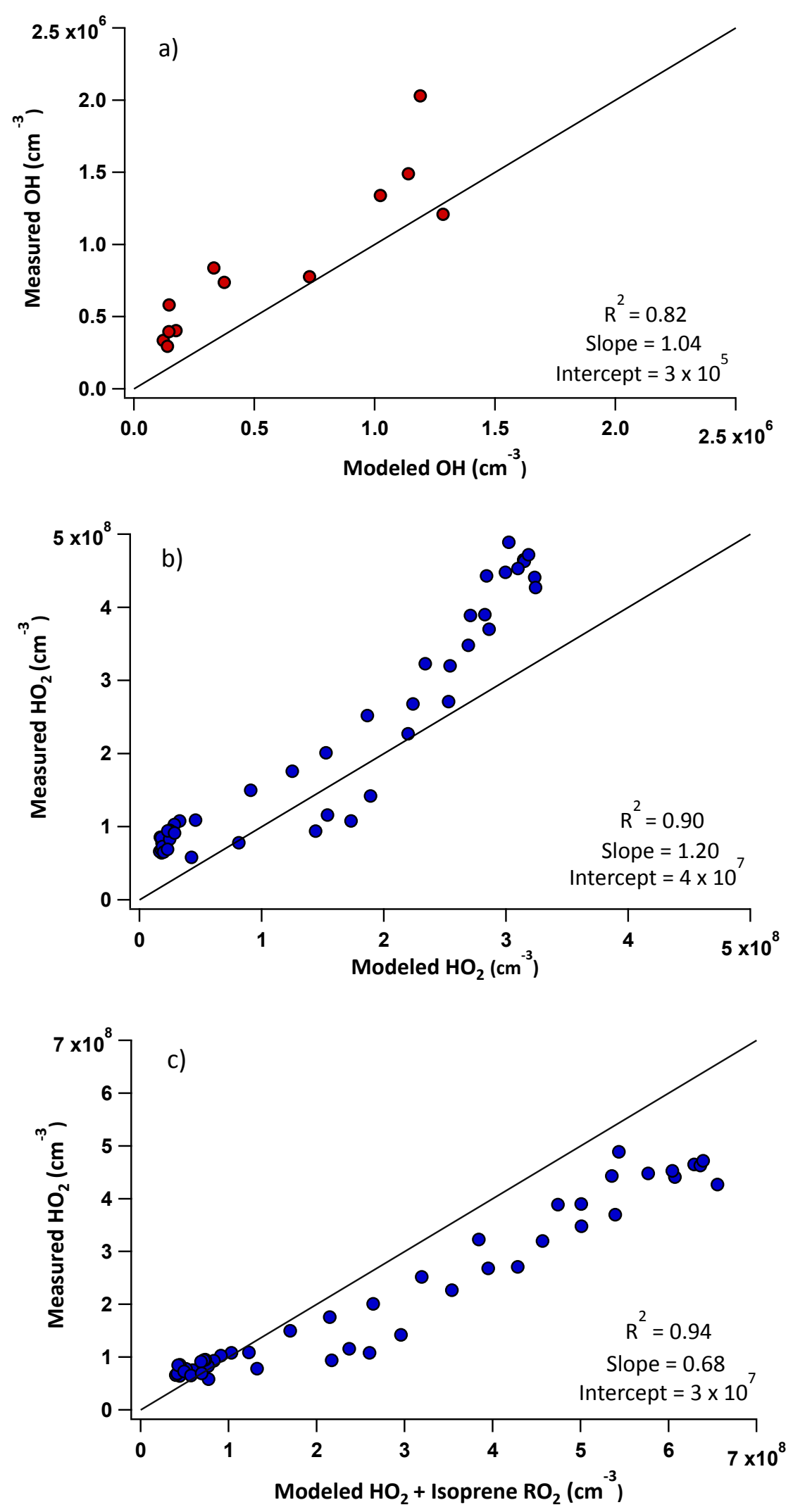

Figure S6. Linear regression of (a) median OH measurements during CABINEX 2009 and 0D model predictions, (b) median $\mathrm{HO}_{2}$ measurements and 0D model predictions, and (c) median $\mathrm{HO}_{2}$ measurements and $\mathrm{HO}_{2}+$ isoprene $\mathrm{RO}_{2} 0 \mathrm{D}$ model predictions. The 1:1 line is included in each plot for reference. 


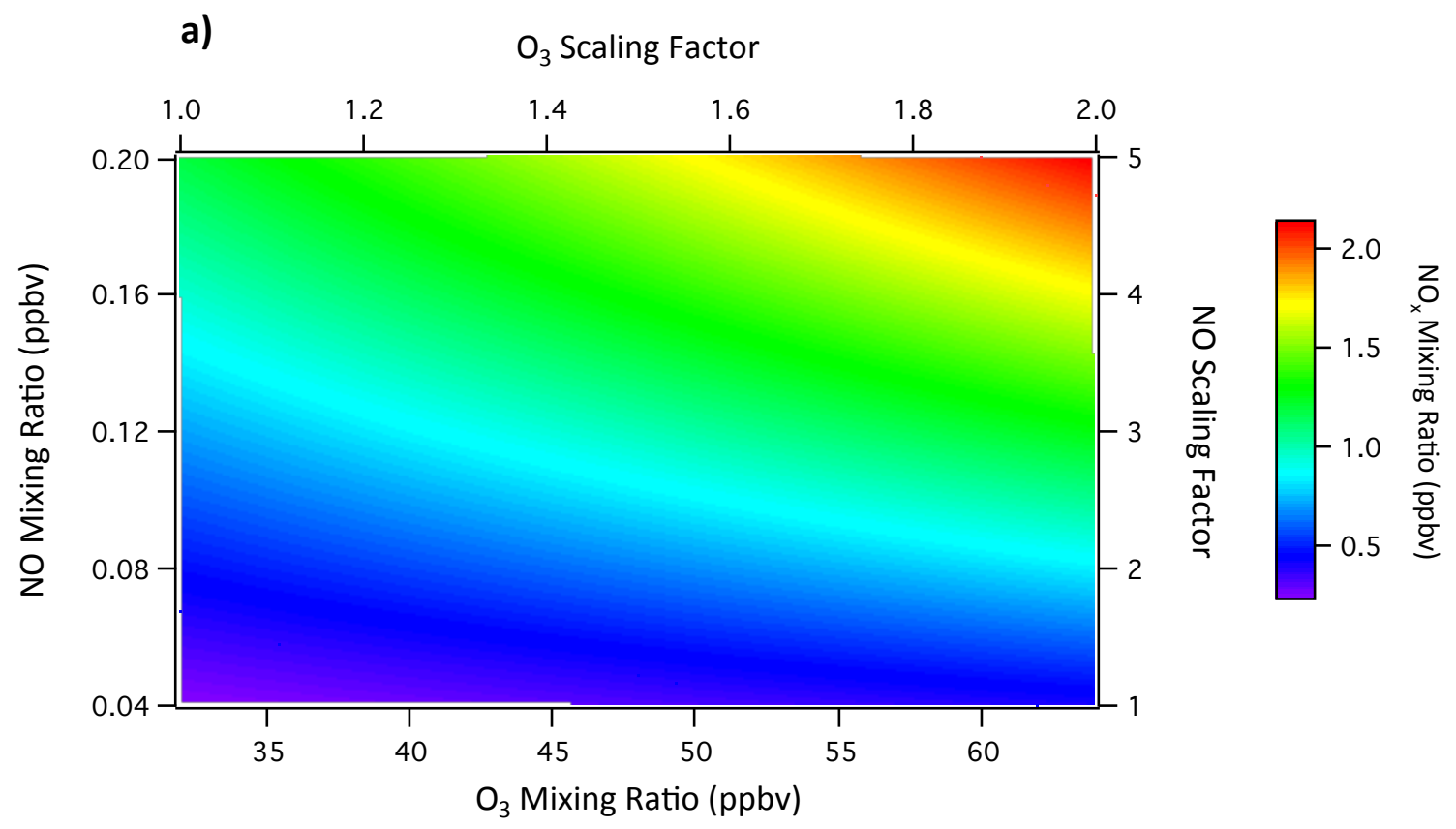

b)

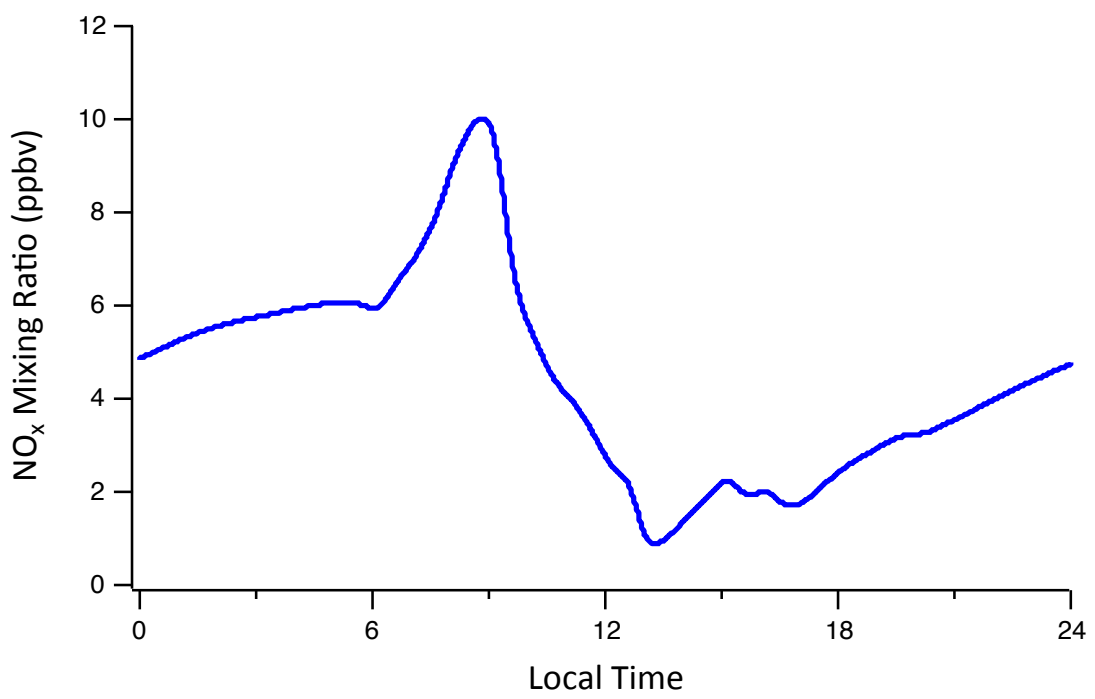

Figure S7. (a) Average $\mathrm{NO}_{\mathrm{x}}$ mixing ratio above the canopy from 11:00-15:00 as a function of $\mathrm{NO}$ and $\mathrm{O}_{3}$ mixing ratios b) Diurnal profile of total above-canopy $\mathrm{NO}_{\mathrm{x}}$ for the most polluted sensitivity test (diurnal profiles of $\mathrm{O}_{3}$ and $\mathrm{NO}$ scaled by factors of 2 and 5 , respectively). 

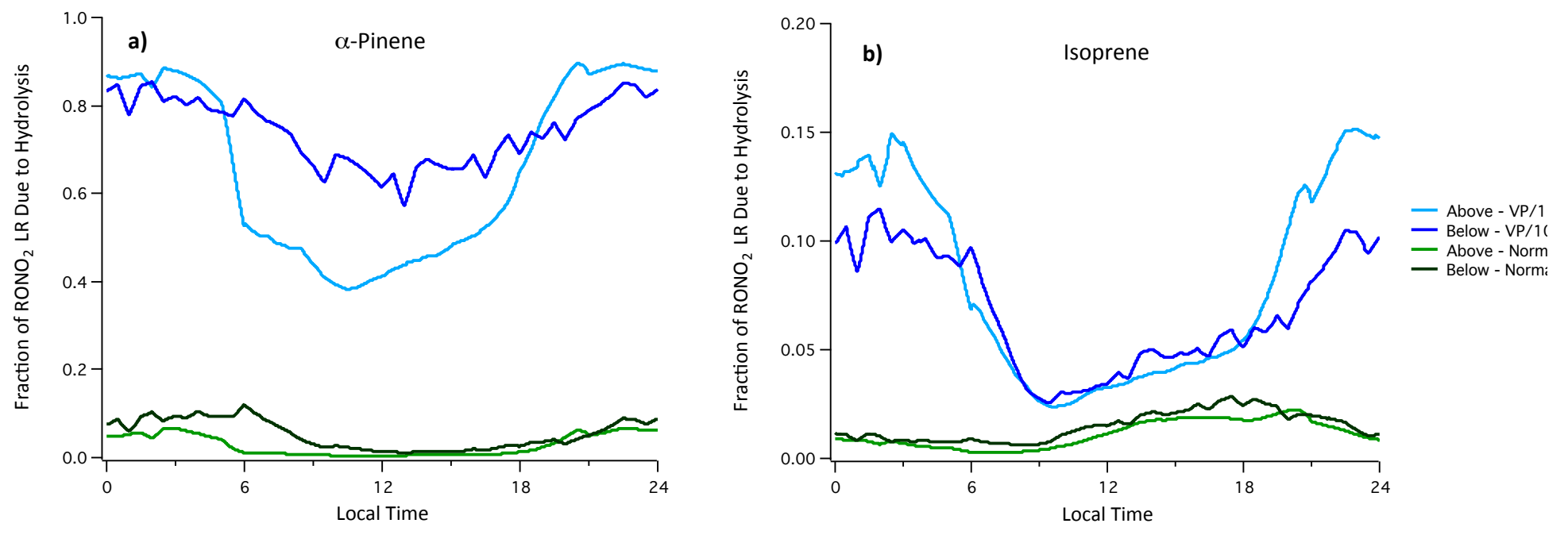

Figure S8. (a) Fraction of total $\alpha$-pinene $\mathrm{RONO}_{2}$ loss rate due to heterogeneous hydrolysis. Green lines represent a scenario using vapor pressures as calculated by the SIMPOL.1 method, while blue lines represent a scenario with all vapor pressures decreased by a factor of 100. Lighter-colored lines indicate above-canopy conditions; darker-colored lines indicate below-canopy conditions. (b) Same as (a), but for isoprene $\mathrm{RONO}_{2}$. Note the different y-axes. Only tertiary isoprene nitrates are assumed to undergo hydrolysis in the model, whereas all $\alpha$-pinene nitrates hydrolyze. 

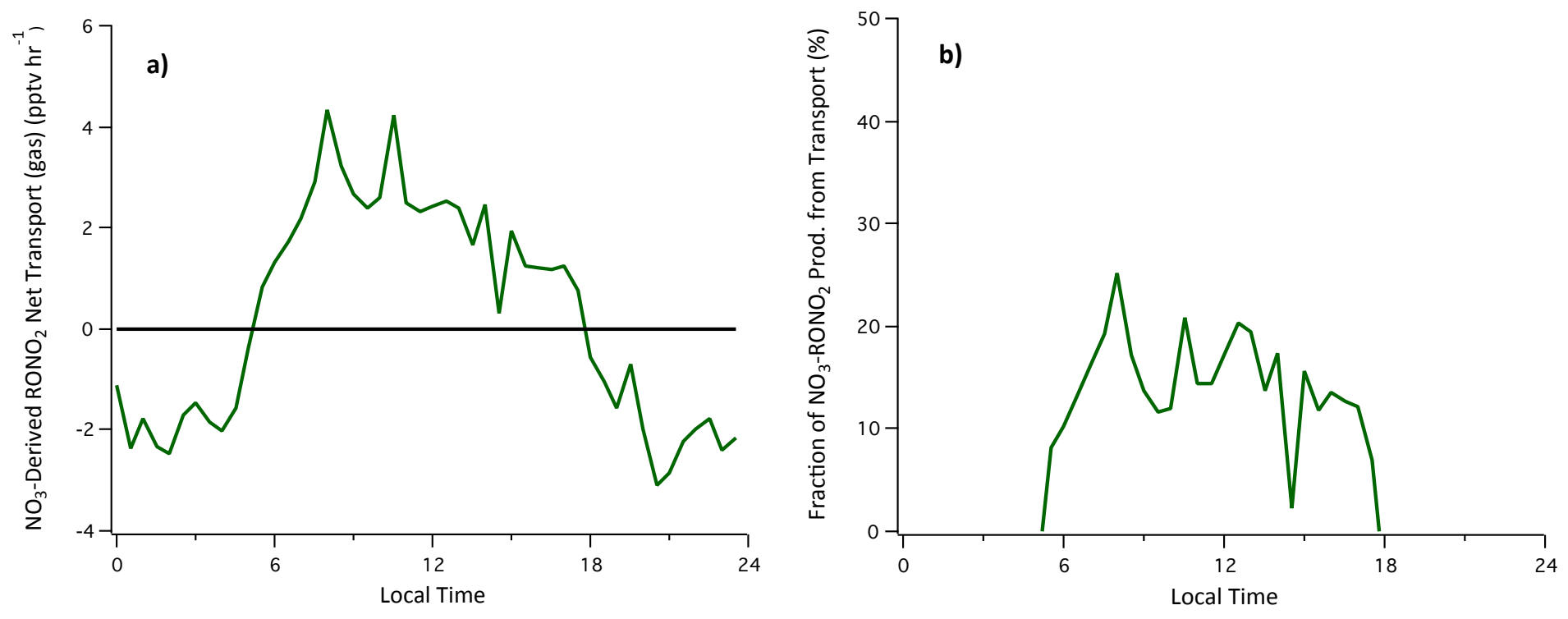

Figure S9. a) Net transport of $\mathrm{NO}_{3}$-derived $\mathrm{RONO}_{2}$ above the canopy assuming all oxidation product vapor pressures are reduced by a factor of 100. Positive indicates transport from the below-canopy environment; negative indicates transport to the below-canopy environment. b) Percent of total $\mathrm{NO}_{3}$-derived $\mathrm{RONO}_{2}$ production contributed by net transport from the below-canopy environment in this scenario. 


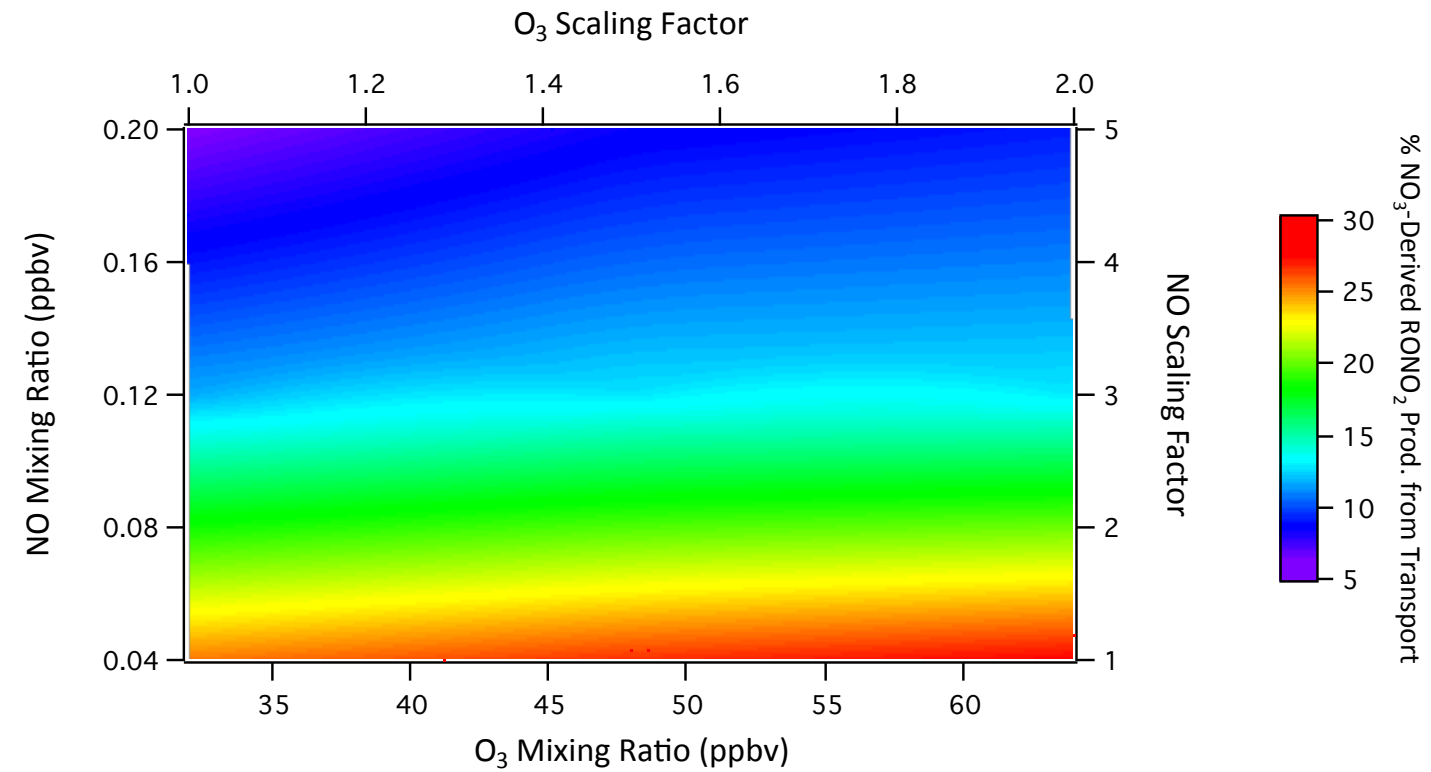

Figure S10. Percent of total $\mathrm{NO}_{3}$-derived $\mathrm{RONO}_{2}$ production contributed by net transport from the below-canopy environment as a function of $\mathrm{O}_{3}$ and $\mathrm{NO}$ mixing ratios. Values represent averages from 11:00 to 15:00. 

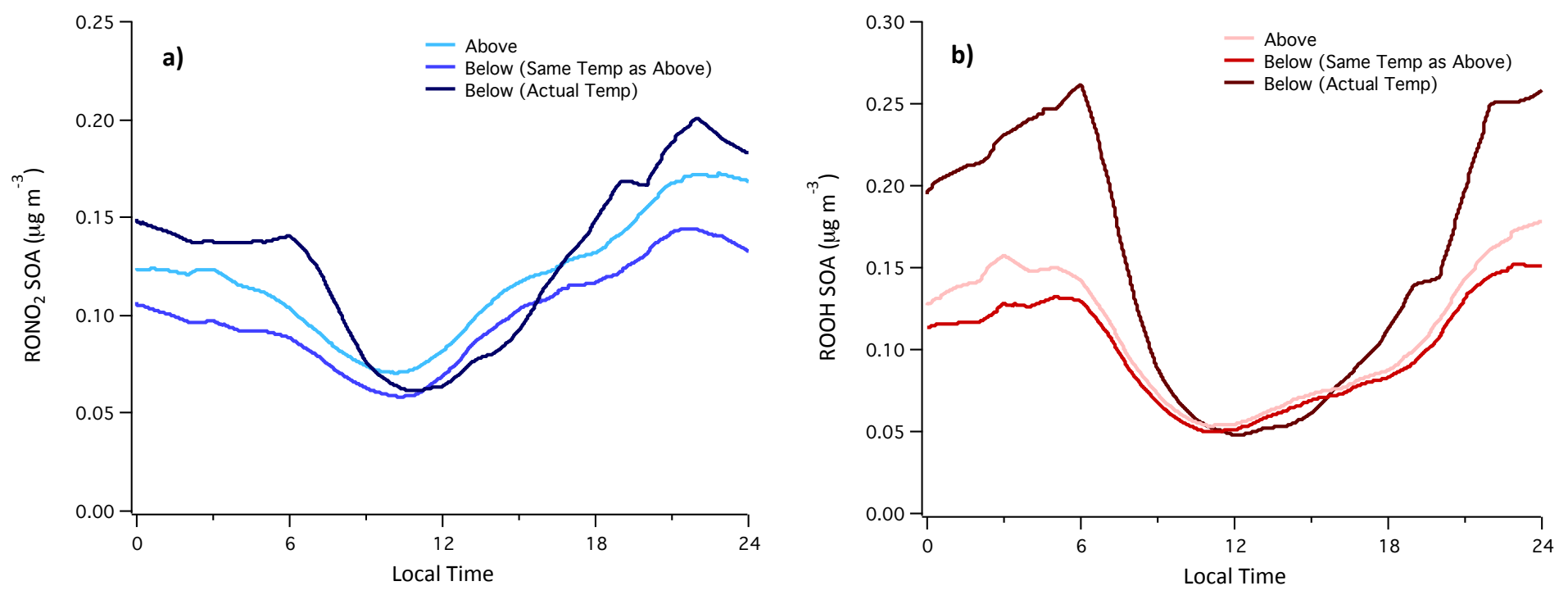

Figure S11. Effect of temperature on semi-volatile SOA formation from (a) $\mathrm{RONO}_{2}$ oxidation products and (b) ROOH oxidation products. The line of intermediate color in each plot (i.e. "medium" darkness) notes the scenario using the same temperature above and below the canopy. 

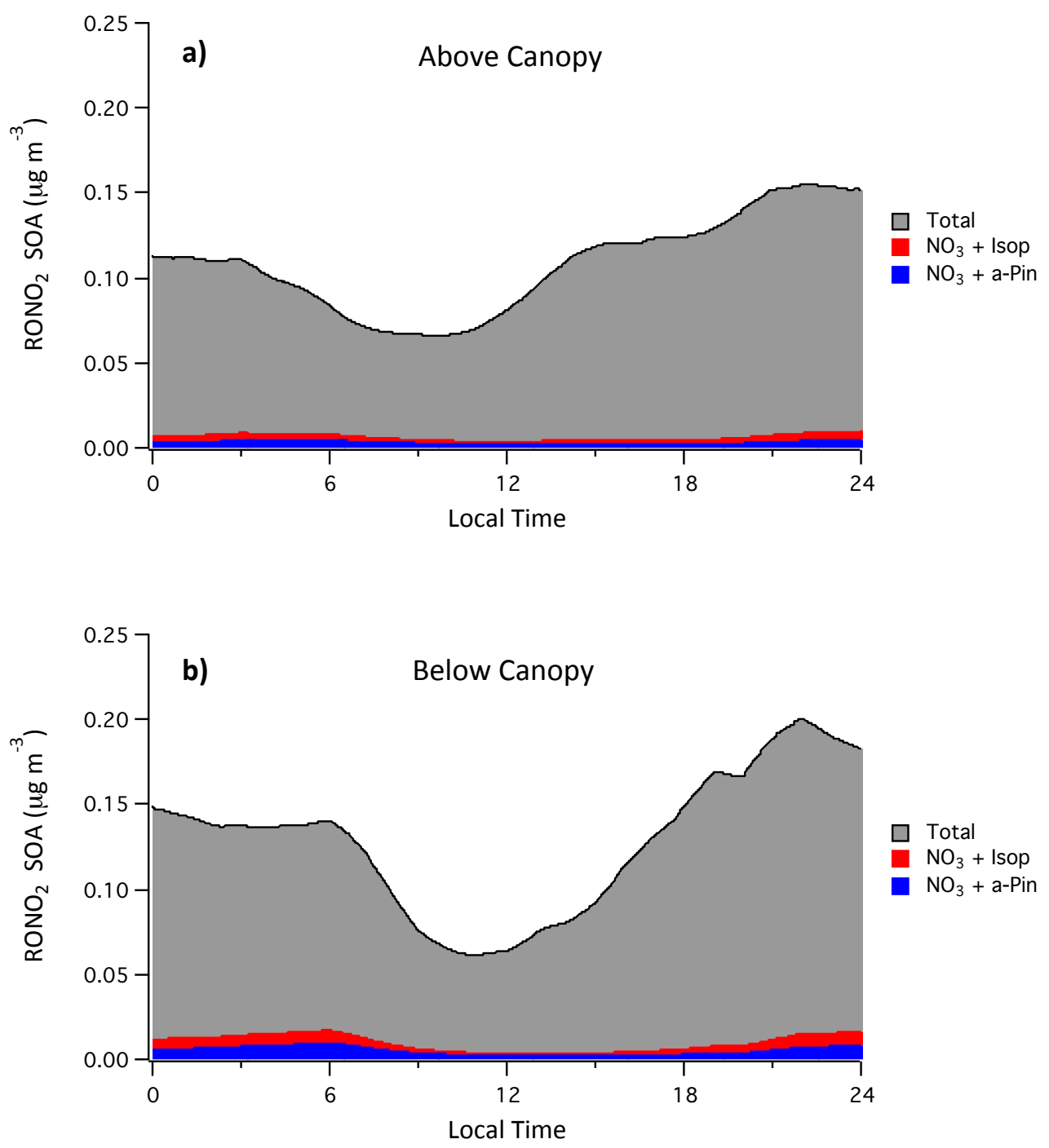

Figure S12. Diurnal profile of total $\mathrm{RONO}_{2} \mathrm{SOA}$ (a) above-canopy and (b) below-canopy including the specific contributions from $\mathrm{NO}_{3}$ oxidation of isoprene and $\alpha$-pinene. 

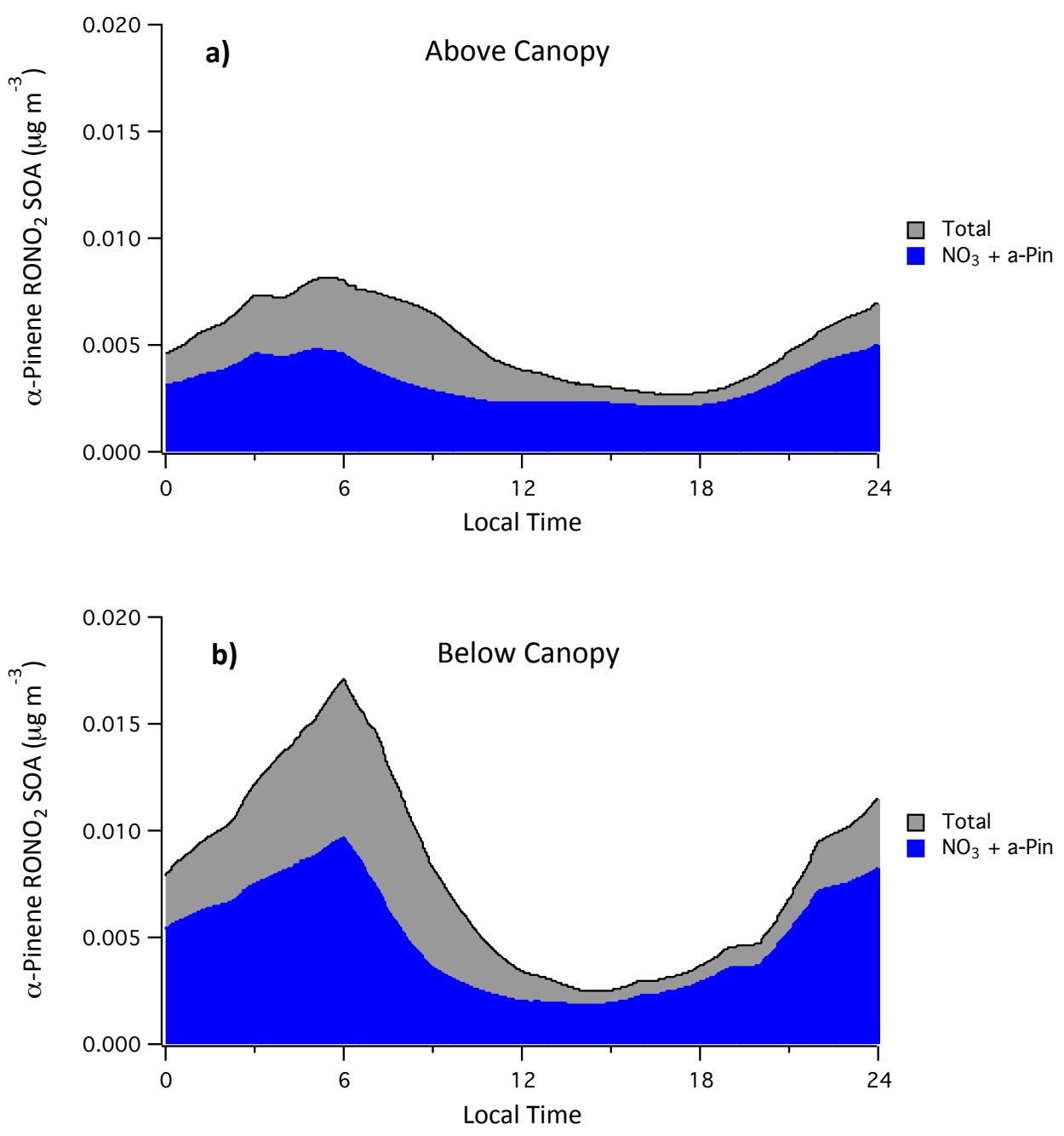

Figure S13. Contribution of $\mathrm{NO}_{3}$ oxidation to total $\alpha$-pinene $\mathrm{RONO}_{2} \mathrm{SOA}_{\text {mass above }}$ (a) and below (b) the canopy. 

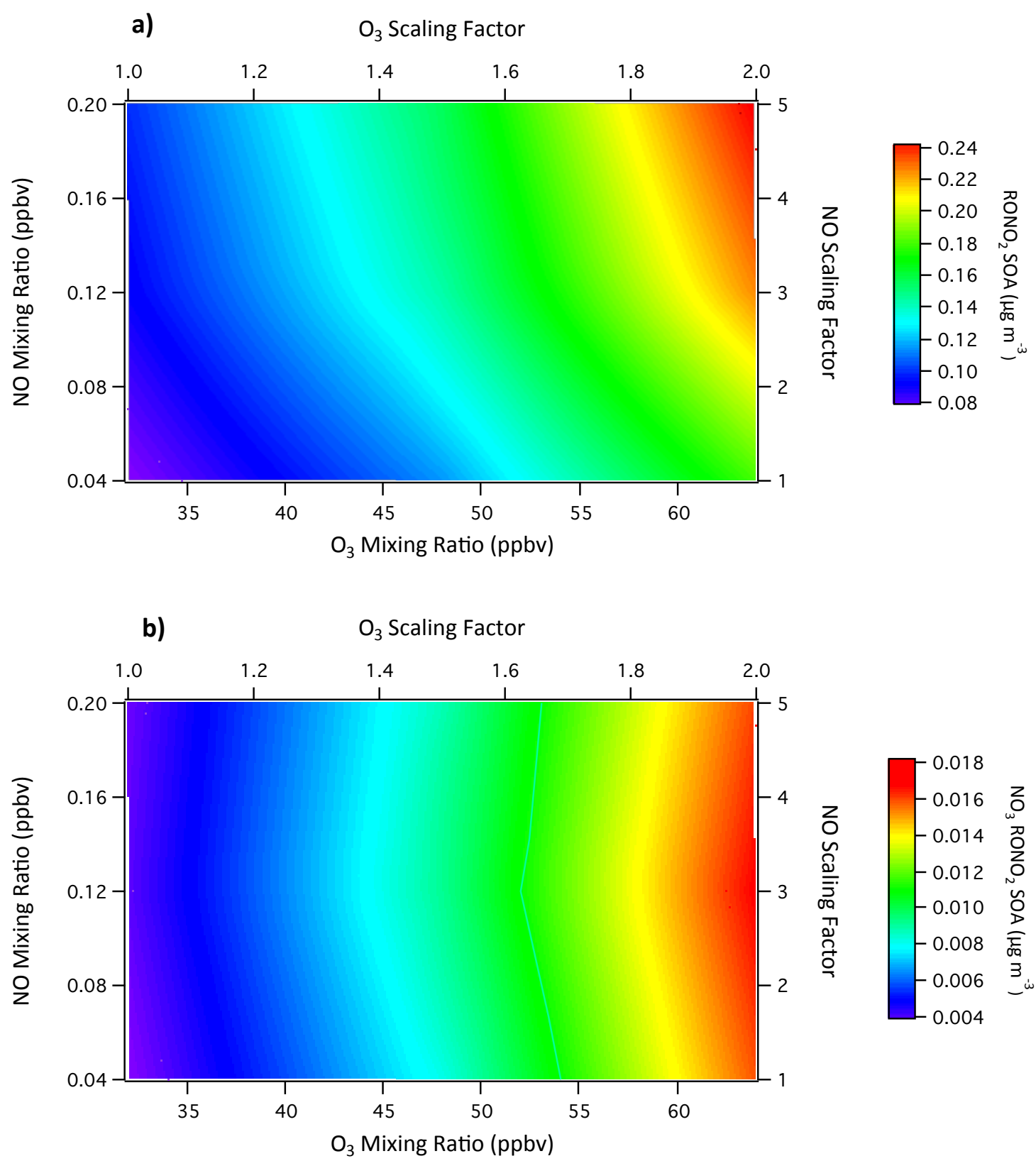

Figure S14. Mass loading of (a) $\mathrm{RONO}_{2} \mathrm{SOA}$ and (b) $\mathrm{NO}_{3}$-derived $\mathrm{RONO}_{2} \mathrm{SOA}$ below the canopy as a function of $\mathrm{O}_{3}$ and $\mathrm{NO}$ mixing ratios. Values are averages from 11:00-15:00. 


\section{Works Cited:}

Ashworth, K., Chung, S. H., Griffin, R. J., Chen, J., Forkel, R., Bryan, A. M., and Steiner, A. L.: FORest Canopy Atmosphere Transfer (FORCAsT) 1.0: a 1-D model of biosphere-atmosphere chemical exchange, Geosci. Model Dev., 8, 3765-3784, doi:10.5194/gmd-8-3765-2015, 2015.

Karl, T., Harley, P., Emmons, L., Thornton, B., Guenther, A., Basu, C., Turnipseed, A., and Jardine, K.: Efficient atmospheric cleansing of oxidized organic trace gases by vegetation, Science, 330, 6005, 816-819, doi:10.1126/science.1192534, 2010.

Nguyen, T. B., Crounse, J. D., Teng, A. P., Clair, J. M. S., Paulot, F., Wolfe, G. M., and Wennberg, P. O.: Rapid deposition of oxidized biogenic compounds to a temperate forest, P. Natl. Acad. Sci. USA, 112, E392-E40, doi:10.1073/pnas.1418702112, 2015.

Sander R.: Compilation of Henry's Law Constants for Inorganic and Organic Species of Potential Importance in Environmental Chemistry (Max Planck Inst Chem, Mainz, Germany), 1999. 